\title{
PENGARUH MEDIA GEOGEBRA TERHADAP MOTIVASI DAN KREATIVITAS BELAJAR MATEMATIKA SISWA SMK NEGERI 1 SINGARAJA
}

\author{
Ni Made Puspitawati ${ }^{1}$, I Wayan Santyasa ${ }^{2}$, Ketut Agustini ${ }^{3}$ \\ ${ }^{123}$ Program Studi Teknologi Pembelajaran, Program Pascasarjana \\ Universitas Pendidikan Ganesha Singaraja, Indonesia
}

email: made.puspitawati@pasca.undiksha.ac.id,santyasa@yahoo.com, ketut.agustini@pasca.undiksha.ac.id

\begin{abstract}
Abstrak
Penelitian ini bertujuan mendeskripsikan pengaruh media pembelajaran terhadap motivasi belajar dan kreativitas siswa setelah perlakuan dikontrol dengan kovariabel motivasi awal dan prakreativitas awal. Penelitian eksperimen semu menggunakan rancangan Pre-testPosttest NonEquivalent Control Group Design. Media pembelajaran memiliki dua dimensi, yaitu media geogegra dan konvensional. Populasi penelitian adalah 10 kelas siswa kelasX SMK Negeri 1 pada Tahun Pelajaran 2015/2016 yang terdiri dari 410 siswa. Sampelnya adalah 2 kelas yaitu kelas X UPWA dan X UPWB dengan jumlah siswa sebanyak 84 orang, dipilih dengan teknik simple random sampling. Data motivasi belajar dan kreativitas dikumpulkan dengan kuisioner motivasi belajar dan kreativitas. Analisis data dilakukan dengan statistik deskriptif dan uji MANCOVA yang dilanjutkan dengan uji Least Significant Difference (LSD) untuk menguji komparasi pasangan skor rata-rata tiap kelompok perlakuan. Setelah perlakuan dikontrol dengan kovariabeel motivasi dan kreativitas awal, hasil penelitian menunjukkan temuan-temuan sebagai berikut. (1) Terdapat perbedaan yang signifikan motivasi belajar dan kreativitas antara siswa yang mengikuti pembelajaran dengan menggunakan media berbasiskan geogebra dibandingkan dengan siswa yang mengikuti pembelajaran dengan media konvensional $(F=141,405 ; p<0,05)$. (2)Terdapat perbedaan signifikan variabel motivasi belajar antara siswa yang mengikuti pembelajaran dengan media berbasiskan geogebra dibandingkan dengan siswa yang belajar dengan menggunakan media konvensional $(F=51,494 ; p<0,05)$. (3) Terdapat perbedaan signifikan variabel kreativitas antara siswa yang mengikuti pembelajaran dengan media berbasiskan geogebra dibandingkan dengan siswa yang mengikuti pembelajaran dengan yang belajar menggunakan media konvensional $(F=182,018 ; p<0,05)$. (4) Hasil uji lanjut dengan LSD menunjukkan bahwa kelompok siswa yang belajar dengan media berbasiskan geogebra lebih baik dibandingkan dengan kelompok siswa yang belajar dengan menggunakan media konvensional.
\end{abstract}

Kata kunci: media geogebra, media konvensional, motivasi belajar, dan kreatifitas belajar .

\begin{abstract}
This study aims atdescribingthe effect of learning media on the learning motivation of students and their creativity. This quasi-experimental usedpre-test posttest design non-equivalent control group design. The learning media have two dimension, e. i algebgra and conventional media. The population was all students of class X SMK Negeri 1 in the academic year 2015/2016 consisting of 10 classes with total population of 410 students. The number of samples in this study consisted of two classes, e. i X UPWA and X UPWB with a total of 84 students were selected by simple random sampling technique. The data of learning motivation and students' creativity were collected by questionnaire. The data was analyzed descriptively and MANCOVA followed by LeastSignificant Difference test (LSD) to test the comparative couples an average score for each treatment group. After the treatment is controlled by covariable premotivation and precreativity,the results showed findings as follows. (1) There are a significant differenceslearning motivation and creativity between students learned use media-based GeoGebra compared to students who learned use conventional media $(F=141.405, p<0,05)$. (2There are a significant difference learning motivation between students learned with media-based GeoGebra compared to students who take the learning by using conventional media $(F=51.494, p<0.05)$. (3) There are a significant difference students' creativity between students learned with media-based GeoGebra compared to students who take the learning by using conventional media $(F=182.018, p$ $<0.05)$. Further test results with LSD showed that the group of students who learned with media-based
\end{abstract}


GeoGebra is better than the group of students who learn with Konvensional Media after treatment is controlled by covariable premotivation and precreativity.

Keywords: media GeoGebra, media Konvensional, learning motivation, and learning creativity.

\section{PENDAHULUAN}

Pada dasarnya suatu kegiatan belajar mengajar (KBM) di dalam kelas dapat diterapkan dalam berbagai metode pembelajaran. Metode pembelajaran disajikan oleh guru dengan harapan siswa sebagai subjek didik dapat menerima bahan pelajaran itu dengan baik dan memberikan hasil yang memuaskan. Apabila dalam penyampaian pelajaran seorang guru selalu menggunakan metode yang konvensional dan dilakukan terus menerus tanpa adanya variasi dalam pembelajaran, dapat dimungkinkan siswa akan menemui kejenuhan karena tidak ada warna baru dalam kegiatan belajar mengajar tersebut.

Perkembangan pesat teknologi informasi kini telah menjadi tantangan bagi dunia pendidikan dan para pendidik khususnya agar dapat bekerja maksimal. Teknologi informasi dapat digunakan sebagai salah satu bagian dari teknologi pendidikan yang mendukung proses

pembelajaran. Penggunaan teknologi informasi ini akan bermanfaat bagi anak didik karena teknologi informasi ini memperhatikan karakteristik, minat dan bakat peserta didik. Keuntungan lain yang menyolok adalah bahwa teknologi informasi dapat mengatasi permasalah ruang waktu dan jarak dalam proses belajar.

Di abad 21 ini penguasaan teknologi informasi dan komunikasi (TIK) merupakan sebuah keharusan baik menjadi sumber belajar, sebagai media belajar maupun menjadi media komunikasi dan kolaborasi. Pada Kurikulum 2013, TIK tidak lagi menjadi mata pelajaran terpisah melainkan terintegrasi dalam setiap mata pelajaran sehingga setiap pendidik mau tidak mau harus menguasai TIK terutama dalam rangka mendukung pembelajaran. Dengan kata lain kompetensi pemanfaatan TIK menjadi salah satu kompetensi wajib yang harus dikuasai setiap pendidik. Pada pembelajaran matematika banyak teknologi yang dapat dimanfaatkan untuk mendukung pembelajaran, baik perangkat keras maupun perangkat lunak.

Tugas pokok seorang guru adalah menfasilitasi siswa belajar. Kata membelajarkan menekankan pada proses belajar siswa, bukan hanya menerima transfer pengetahuan dari guru. Keberhasilan dalam melaksanakan proses belajar mengajar dipengaruhi oleh banyak faktor. Kunandar (2007) mengatakan bahwa keberhasilan proses belajar mengajar dipengaruhi oleh: (1) diri siswa sendiri sebagai pelaku utama dalam proses belajar mengajar; (2) diri guru sebagai pengelola proses belajar mengajar dengan segala keunikannya; (3) tujuan pembelajaran yang menjadi sasaran pencapaian dari proses belajar mengajar; (4) bahan pengajaran sebagai penunjang pokok bagi tercapainya tujuan; (5) kemudahan untuk mencapai sumber bahan pengajaran; (6) suasana sekitar pada waktu belajar.

Sejalan dengan itu, Arsyad (2006) mengatakan bahwa dalam suatu proses belajar mengajar, dua unsur yang amat penting adalah metode mengajar dan media pembelajaran. Kedua aspek ini saling berkaitan. Pemilihan salah satu metode mengajar tertentu akan mempengaruhi jenis media pembelajaran yang sesuai, meskipun masih ada berbagai aspek lain yang harus diperhatikan dalam memilih media, antara lain tujuan pembelajaran, jenis tugas dan respon yang diharapkan siswa kuasai setelah pembelajaran berlangsung, dan konteks pembelajaran termasuk karakteristik siswa. Meskipun demikian, dapat dikatakan bahwa salah satu fungsi utama media pembelajaran adalah sebagai alat bantu mengajar yang turut mempengaruhi iklim, kondisi, dan lingkungan belajar yang ditata dan diciptakan oleh guru. 
Fatah Syukur (2005) menyatakan intinya bahwa dalam proses belajar mengajar akan efektif apabila terdapat guru yang professional yang mampu menyelaraskan antara media pendidikan yang ada dengan metode pembelajaran. Jadi antara materi ajar, metode, dan media pembelajaran yang digunakandalam proses belajar mengajar didunia pendidikan harus selaras dan sesuai. Dengan kata lain media pembelajaran harus sesuai dengan metode pembelajaran yang dipakai oleh guru. Metode pembelajaran harus sesuai dengan materi pembelajaran yang akan disampaikan oleh guru kepada peserta didiknya

Berdasarkan uraian tersebut dapat dikatakan bahwa guru merupakan salah satu komponen yang sangat menentukan keberhasilan siswa dalam belajar. Oleh karena itu guru haruslah selalu berusaha untuk menemukan strategi/metode yang tepat dalam pembelajaran sehingga siswa termotivasi untuk belajar, lebih kreatif dan pada akhirnya dapat meningkatkan hasil belajar.

Siswa yang termotivasi dalam belajarnya dapat dilihat dari karakteristik tingkah laku yang menyangkut minat, ketajaman, perhatian, konsentrasi, dan ketekunan. Siswa yang memiliki motivasi rendah dalam belajarnya menampakkan keengganan, cepat bosan dan berusaha menghindar dari kegiatan belajar. Berhasil atau gagalnya dalam membangkitkan dan mendayagunakan motivasi dalam proses pembelajaran berkaitan dengan upaya pembinaan disiplin kelas. Masalah disiplin kelas dapat timbul karena kegagalan dalam pergerakan motivasi belajar. Penggunaan asas motivasi merupakan sesuatu yang esensial dalam proses belajar dan pembelajaran. Motivasi menjadi salah satu faktor yang turut menentukan pembelajaran yang efektif (Hamalik, 2001).

Berdasarkan uraian di atas, bahwa faktor motivasi sangatlah berpengaruh terhadap proses pembelajaran, motivasi menentukan tingkat berhasil atau gagalnya kegiatan siswa, dan motivasi merupakan salah satu faktor yang turut menentukan pembelajaran yang efektif. Belajar tanpa motivasi sulit untuk mencapai keberhasilan secara optimal.

Kreativitas merupakan hal yang sangat penting dimiliki oleh setiap individu. Ada beberapa alasan mengapa kreativitas penting dipupuk dan dikembangkan dalam diri siswa, seperti yang dikemukakan oleh beberapa ahli sebagai berikut: 1) karena dengan berkreasi siswa dapat mewujudkan dirinya, dan perwujudan diri termasuk salah satu kebutuhan pokok dalam proses pembelajaran (Maslow, 1968); 2) kreativitas atau berpikir kreatif, sebagai kemampuan untuk melihat bermacam-macam kemungkinan penyelesaian masalah (Guilford, dalam Munandar, 1992) bersibuk diri dalam kreatif tidak hanya bermanfaat, tetapi juga dapat memberikan kepuasan kepada individu (Biondi, 1972).

Menghadapi masa sekarang dengan kemajuan dan perubahan yang begitu cepat dalam bidang ilmu pengetahuan dan teknologi, pendidik tidak dapat meramalkan dengan tepat macam pengetahuan apa yang akan dibutuhkan seorang anak lewat sepuluh tahun atau lebih untuk menghadapi masalah-masalah kehidupan apabila ia sudah dewasa (Munandar, 1992). Lebih lanjut Munandar mengatakan bahwa upaya lain yang dapat dilakukan oleh pendidik adalah mengembangkan sikap dan kemampuan anak didiknya yang dapat membantu untuk menghadapi persoalan-persoalan di masa mendatang secara kreatif dan inventif. Menjejalkan bahan pengetahuan sematamata tidak akan banyak menolong siswa, karena belum tentu di masa mendatang ia dapat menggunakan informasi tersebut. Hasil penelitian Munandar (1992) menunjukkan bahwa perkembangan optimal dari kemampuan berpikir kreatif berhubungan erat dengan cara mengajar.

Sebagai negara yang berkembang Indonesia sangat membutuhkan tenagatenaga kreatif yang mampu memberikan sumbangan bermakna kepada ilmu pengetahuan, teknologi dan kesenian, serta kepada kesejahteraan bangsa pada umumnya. Sehubungan dengan ini pendidikan hendaknya tertuju kepada 
pengembangan kreativitas peserta didik agar kelak dapat memenuhi kebutuhan pribadi dan kebutuhan masyarakat serta negara.

Sehubungan dengan kreativitas, Munandar (1992) mengatakan bahwa kreativitas merupakan kemampuan untuk membuat kombinasi baru, berdasarkan data, informasi atau unsur-unsur yang ada. Lebih lanjut dikatakan bahwa gagasan dan hasil karya yang kreatif tidak muncul begitu saja. Untuk dapat mencipta sesuatu yang bermakna dibutuhkan persiapan. Demikian juga semua data (pengalaman) memungkinkan seseorang menciptakan, yaitu dengan menggabung-gabungkan (mengkombinasi) unsur-unsurnya menjadi sesuatu yang baru. Hal ini tidak berarti bahwa makin banyak pengalaman dan pengetahuan seseorang makin kreatif. Pengalaman dan pengetahuan memungkinkannya untuk mencipta, lebih daripada seseorang yang tidak mempunyai banyak pengalaman dan pendidikan. Dari uraian tentang kreativitas tersebut, ada tiga tekanan kemampuan, yaitu yang berkaitan dengan kemampuan untuk mengkombinasi, memecahkan masalah/menjawab masalah dan cermin kemampuan operasional anak kreatif. Adapun ketiga penekanan kemampuan tersebut yaitu: (1) Kemampuan untuk membuat kombinasi baru berdasarkan data, informasi atau unsur-unsur yang ada; (2) kemampuan berdasarkan data atau informasi yang tersedia, menemukan banyak kemungkinan jawaban terhadap suatu masalah, dimana penekanannya adalah pada kuantitas, ketepatgunaan dan keragaman jawaban; dan (3) kemampuan yang secara operasional mencerminkan kelancaran, keluwesan dan orisinalitas dalam berpikiir, serta kemampuan untuk mengelaborasi suatu gagasan. (Munandar dalam Hawadi, et al, 2001)

Mengingat bahwa kreativitas merupakan bakat yang secara potensial dimiliki oleh setiap orang, yang dapat temukenali (identifikasi) dan dipupuk melalui pendidikan yang tepat, salah satu masalah yang kritis ialah bagaimana dapat menemukenali potensi kreatif siswa dan bagaimana dapat mengembangkannya melalui pengalaman pendidikan.

Berdasarkan uraian tersebut di atas, untuk dapat mewujudkan motivasi belajar dan kreativitas siswa, serta siswa dapat mempraktekkan secara langsung apa yang dipelajarinya, maka diperlukan adanya media pembelajaran yang representatif dalam proses belajar mengajar sesuai dengan karakteristik materi dan tujuan pembelajaran. Hal ini diperkuat oleh hasil penelitian yang dilakukan Sadaan dan Kuan Eu (2014) bahwa terdapat peningkatan signifikan pemahaman siswa yang menggunakan geogebra terhadap materi lingkaran. Penggunaan geogebra tidak saja meningkatkan nilai siswa tetapi juga mampu menciptakan kooperatif dan kolaboratif di kalangan siswa. Hasil penelitian juga menunjukkan menghasilkan motivasi luar biasa dan kepercayaan diri pada siswa yang menggunakan geogebra. Hal sama ditunjukkan pula hasil penelitian Putrawan dan Suharta (2014) bahwa penggunaan perangkat pembelajaran matematika dengan pendekatan scientific berbantuan geogebra yang valid, praktis dan efektif. memberikan dampak terhadap meningkatnya keterampilan komunikasi dan aktivitas belajar siswa. Penggunaan media yang memadai dalam proses belajar mengajar didasarkan atas asumsi bahwa guru berhadapan dengan siswa yang berbeda antara yang satu dengan yang lainnya. Perbedaan tersebut bisa dilihat dari segi minat, bakat, tingkat kecerdasan, termasuk kemampuan dalam mengkonstruksi atau membangun pengetahuan sendiri melalui pengetahuan yang telah dimiliki sebelumnya.

Pengembangan variasi mengajar yang dilakukan oleh guru salah satunya adalah dengan memanfaatkan variasi alat bantu atau media pembelajaran. Media pendidikan sebagai produk dari teknologi semakin bervariasi mulai dari yang sederhana hingga yang canggih. Media cetak dan elektronik pun pada dasarnya memiliki potensi untuk menunjang kegiatan pendidikan dan pembelajaran.

Pada dasarnya suatu kegiatan belajar mengajar (KBM) di dalam kelas 
dapat diterapkan dalam berbagai metode pembelajaran. Metode pembelajaran disajikan oleh guru dengan harapan siswa sebagai subjek didik dapat menerima bahan pelajaran itu dengan baik dan memberikan hasil yang memuaskan. Apabila dalam penyampaian pelajaran seorang guru selalu menggunakan media konvensional dan dilakukan terus menerus tanpa adanya variasi dalam pembelajaran, dapat dimungkinkan siswa akan menemui kejenuhan karena tidak ada warna baru dalam kegiatan belajar mengajar tersebut.

Perkembangan pesat teknologi informasi kini telah menjadi tantangan bagi dunia pendidikan dan para pendidik khususnya agar dapat bekerja maksimal. Teknologi informasi dapat digunakan sebagai salah satu bagian dari teknologi pendidikan yang mendukung proses pembelajaran. Penggunaan teknologi informasi ini akan bermanfaat bagi anak didik karena teknologi informasi ini memperhatikan karakteristik, minat dan bakat peserta didik. Keuntungan lain yang menyolok adalah bahwa teknologi informasi dapat mengatasi permasalah ruang waktu dan jarak dalam proses belajar.

Pembelajaran
menggunakan media diduga dapat
membangkitkan motivasi belajar siswa
serta diduga pula dapat meningkatkan
kreativitas siswa. Pembelajaran dengan
menggunakan media memberikan
kesempatan untuk belajar tidak hanya dari
satu sumber belajar seperti guru, tetapi
memberikan kesempatan kepada subjek
mengembangkan kognitif dengan lebih
baik, kreatif dan inovatif.
baik, kreatif dan inovatif.

Dalam kaitannya dengan penggunaan metode dan media pembelajaran, hasil observasi serta wawancara dengan beberapa guru yang mengajar mata Matematika di SMK Negeri 1 Singaraja pada semester ganjil Tahun Pelajaran 2014/2015, bahwa metode pembelajaran yang digunakan oleh para guru selama ini pada prinsipnya sama, yaitu metode ceramah, diskusi kelompok, tanya jawab, ataupun cara-cara lainnya. Demikian pula dengan media yang digunakan masih sangat sederhana, sehingga media yang disajikan kurang menarik perhatian siswa. Pembelajaran secara konvensional seperti ini memungkinkan siswa suatu saat akan mengalami kejenuhan.

Pembelajaran dengan media konvensional yang dimaksud yaitu pembelajaran yang dilakukan oleh guru dengan menggunakan metode ceramah, serta dilanjutkan dengan tanya jawab dan pemberian tugas kepada siswa dengan menggunakan media millimeter blok. Penggunaan media millimeter blok diduga belum dapat mengakomodasi kemampuan beberapa siswa, serta pemanfaatannya pun masih didominasi oleh guru.

Belum optimalnya pembelajaran yang telah dilakukan dapat dilihat dari proses maupun dari segi hasil belajar siswa. Dari segi proses, pembelajaran yang terjadi belum dapat membangkitkan motivasi dan minat siswa dalam belajar. Hal ini ditunjukkan oleh prilaku siswa yang cepat merasa bosan dalam mengikuti pelajaran. Siswa sudah merasa puas jika ia mampu mengikuti petunjuk penyelesaian soal-soal tanpa harus memahami bagaimana hal itu diperolehnya. Sedangkan dilihat dari hasil belajar siswa masih tergolong cukup yaitu baru mencapai rata-rata 6,82 pada nilai sumatif semester I tahun pelajaran 2014/2015.

Sehubungan dengan penggunaan media dalam pembelajaran, ada beberapa hasil penelitian yang membahas tentang penggunaan berbagai jenis media. Badung (2000) mengatakan bahwa peningkatan motivasi belajar terjadi disebabkan guru lebih memvariasikan media dalam pembelajaran. Senada dengan itu adalah hasil penelitian Yusufhadi Miarso (dalam Aryati, 2000) yang menyatakan bahwa pemanfaatan media secara tepat berguna untuk menumbuhkan sikap positif anak didik dalam belajar, menimbulkan kegairahan belajar, memungkinkan interaksi langsung antara siswa dengan lingkungan serta memungkinkan belajar sendiri menurut kemampuan dan minat anak didik. Aryati (2000) menemukan bahwa dengan penerapan multimedia dalam pembelajaran, siswa akan lebih 
mudah memahami apa yang diajarkan oleh guru. Sejalan dengan hasil temuan Saroso (2008), bahwa penggunaan teknologi informasi dan multimedia dalam pembelajaran memiliki beberapa kelebihan, yaitu: (1) sistem pembelajaran dengan multimedia lebih inovatif dan interaktif; (2) multimedia mampu menggabungkan antara teks, gambar, audio, musik, animasi gambar atau video dalam satu kesatuan yang saling mendukung guna tercapainya tujuan pembelajaran; (3) mampu menimbulkan rasa senang selama proses belajar mengajar berlangsung. Hal ini akan menambah motivasi siswa selama proses belajar mengajar, sehingga didapatkan tujuan pembelajaran yang optimal; (4) mampu memvisualisasikan materi yang selama ini sulit untuk diterangkan hanya sekedar dengan penjelasan atau alat peraga yang konvensional; dan (5) media penyimpanan yang relatif gampang dan fleksibel.

dalam $\begin{gathered}\text { Penggunaan media geogebra } \\ \text { pembelajaran matematika }\end{gathered}$ membantu siswa dalam mengembangkan kreatifitas, aktivitas dan motivasi serta mampu meningkatkan pemahaman, dan prestasi belajar siswa. Hal ini sejalan dengan hasil penelitian yang dilakukan Alit (2014 ) menemukan bahwa aplikasi GeoGebra dapat dimanfaatkan untuk meningkatkan pemahaman siswa terhadap karakteristik grafik fungsi kuadrat. Zakaria dan Effandi (2014) menunjukkan bahwa penggunaan GeoGebra telah berhasil meningkatkan pengetahuan konseptual dan prosedural siswa pada mater fungsi limit. Menggunakan perangkat lunak GeoGebra memungkinkan guru untuk menyajikan gambar pada konsep fungsi dan fungsi limit. Kuan Eu (2014) menemukan bahwa terdapat peningkatan signifikan pemahaman siswa yang menggunakan geogebra terhadap materi lingkaran. Noviyanti (2014) menemukan bahwa pembelajaran dengan media geogebra memberikan dampak terhadap meningkatnya keterlibatan siswa dalam pembelajaran terlihat dari interaksi siswa dengan siswa dan siswa dengan guru. Selain meningkatkan keterlibatan siswa juga meningkatnya prestasi belajar matematika siswa khusunya pada pembelajaran geometri.

Berdasarkan latar belakang yang telah diuraikan, maka dapat dirumuskan permasalahan sebagai berikut. Pertama, Setelah perlakuan dikontrol dengan kovariabel pramotivasi dan prakreativitas apakah terdapat perbedaan motivasi belajar dan kreativitas antara siswa yang mengikuti pembelajaran dengan menggunakan media berbasisikan geogebra dibandingkan dengan siswa yang mengikuti pembelajaran dengan media konvensional?. Kedua, Setelah perlakuan dikontrol dengan kovariabel pramotivasi dan prakreativitas apakah terdapat perbedaan motivasi belajar antara siswa yang mengikuti pembelajaran dengan menggunakan media berbasiskan geogebra dibandingkan dengan siswa yang mengikuti pembelajaran dengan media konvensional?.Ketiga, Setelah perlakuan dikontrol dengan kovariabel pramotivasi dan prakreativitas apakah terdapat perbedaan kreativitas antara siswa yang mengikuti pembelajaran dengan menggunakan media berbasiskan geogebra dibandingkan dengan siswa yang mengikuti pembelajaran dengan media konvensional?. Sesuai dengan permasalahan-permasalahan yang telah diuraikan tersebut, maka tujuan penelitian ini adalah sebagai berikut. Pertama, menganalisis perbedaan motivasi belajar dan kreativitas antara siswa yang mengikuti pembelajaran dengan menggunakan media berbasiskan geogebra dibandingkan dengan siswa yang mengikuti pembelajaran dengan media konvensional, setelah perlakuan dikontrol dengan kovariabel pramotivasi dan prakreativitas. Kedua, menganalisis perbedaan motivasi belajar antara siswa yang mengikuti pembelajaran dengan media berbasiskan geogebra dibandingkan dengan siswa yang mengikuti pembelajaran dengan media konvensional, setelah perlakuan dikontrol dengan kovariabel pramotivasi. Ketiga, menganalisis perbedaan kreativitas antara siswa yang mengikuti pembelajaran dengan media berbasiskan geogebra 
dibandingkan dengan siswa yang mengikuti pembelajaran dengan media konvensional, setelah perlakuan dikontrol dengan kovariabel prakreativitas.

\section{METODE}

Penelitian ini merupakan penelitian kuasi eksperimen yang dilakukan pada siswa kelas $X$ SMK N 1Singaraja tahun pelajaran 2015/2016. Eksperimen menggunakan rancangan the non equivalentpre test and post test controlgroup desaign. Populasi dari penelitian ini adalah seluruh siswa kelas $X$ di SMK $N$ 1Singaraja yang terdistribusi menjadi 10 kelas. Dengan teknik random sampling, terpilih kelas $X$ UPWB yang dikenai media Geogebra, kelas X UPWA dikenai MK. Data yang diperlukan dalam penelitian ini adalah skor-skor motivasi dan kreativitas belajar siswa. Data dikumpulkan dengan kuisioner motivasi dan kreativitas belajar terdiri dari 35 butir pernyataan. Sebelum dilakukan pengujian hipotesis maka data penelitian harus memenuhi syarat analisis yang meliputi uji normalitas sebaran data, uji homogenitas varians, uji linieritas, uji kolinieritas, dan uji homogenits matrik varian/kovarian. Uji normalitas sebaran data menggunakan statistik KolmogorovSmirnov dan Shapiro-Wilk, uji homogenitas varians menggunakan statistik Levene, uji kolinieritas dengan korelasi product momentdan ujihomogenits matrik varian/kovarian menggunakan Box'M. Selanjutnya data dianalisis secara deskriptif dan dengan menggunakan MANCOVA dan diuji lanjut dengan menggunakan LSD. Semua pengujian hipotesis dilakukan pada taraf signifikansi 0,05 dan dengan bantuan program SPSS 17.0 for windows.

\section{HASIL DAN PEMBAHASAN}

Deskripsi umum hasil pre-tes dan pos-tes kreativitas dan motivasi belajar siswa yang diungkap terdiri dari distribusi frekuensi, distribusi nilai rata-rata $(\bar{X})$, dan standar deviasi (SD) berdasarkan pembelajaran dengan media geogebra dan pembelajaran dengan media konvensional yang diberikan untuk masing-masing kelompok perlakuan.disajikan pada Tabel 1 dan Tabel 2 berikut

Tabel 1 Rekapitulasi Hasil Perhitungan Skor Kreatifitas Belajar Matematika Siswa

\begin{tabular}{|c|c|c|c|c|}
\hline Data & \multicolumn{2}{|c|}{ MEDIA GEOGEBRA } & \multicolumn{2}{|c|}{ MEDIA KONVENSIONAL } \\
\hline Statistik & Pre-test & Post-test & Pre-test & Post-test \\
\hline Mean & 97,43 & 113,40 & 97,69 & 99,29 \\
\hline Median & 96,50 & 113,00 & 98,00 & 98,50 \\
\hline Std. Deviasi & 8,827 & 10,716 & 6,856 & 7,095 \\
\hline Varians & 77,909 & 114,832 & 46,999 & 50,355 \\
\hline Nilai Minimum & 76 & 82 & 81 & 82 \\
\hline Nilai Maksimum & 123 & 136 & 118 & 121 \\
\hline Rentangan & 47 & 54 & 37 & 39 \\
\hline Jumlah & 4092 & 4763 & 4103 & 4170 \\
\hline
\end{tabular}

Berdasarkan Tabel 1, dapat dinyatakan bahwa secara statistik deskriptif kreativitas siswa yang belajar dengan menggunakan media geogebra lebih baik dari siswa yang belajar dengan Media Konvensional

Tabel 2 Rekapitulasi Hasil Perhitungan Skor Motivasi Belajar Siswa

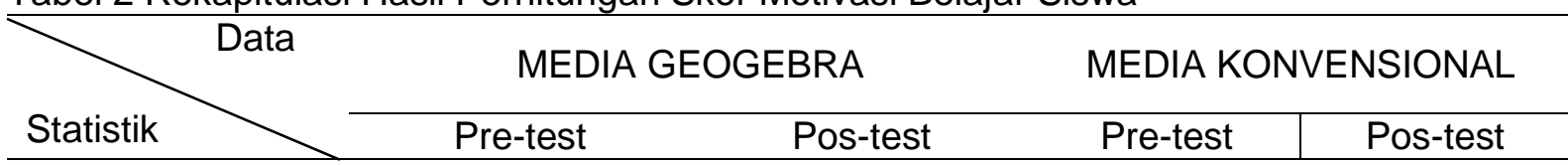




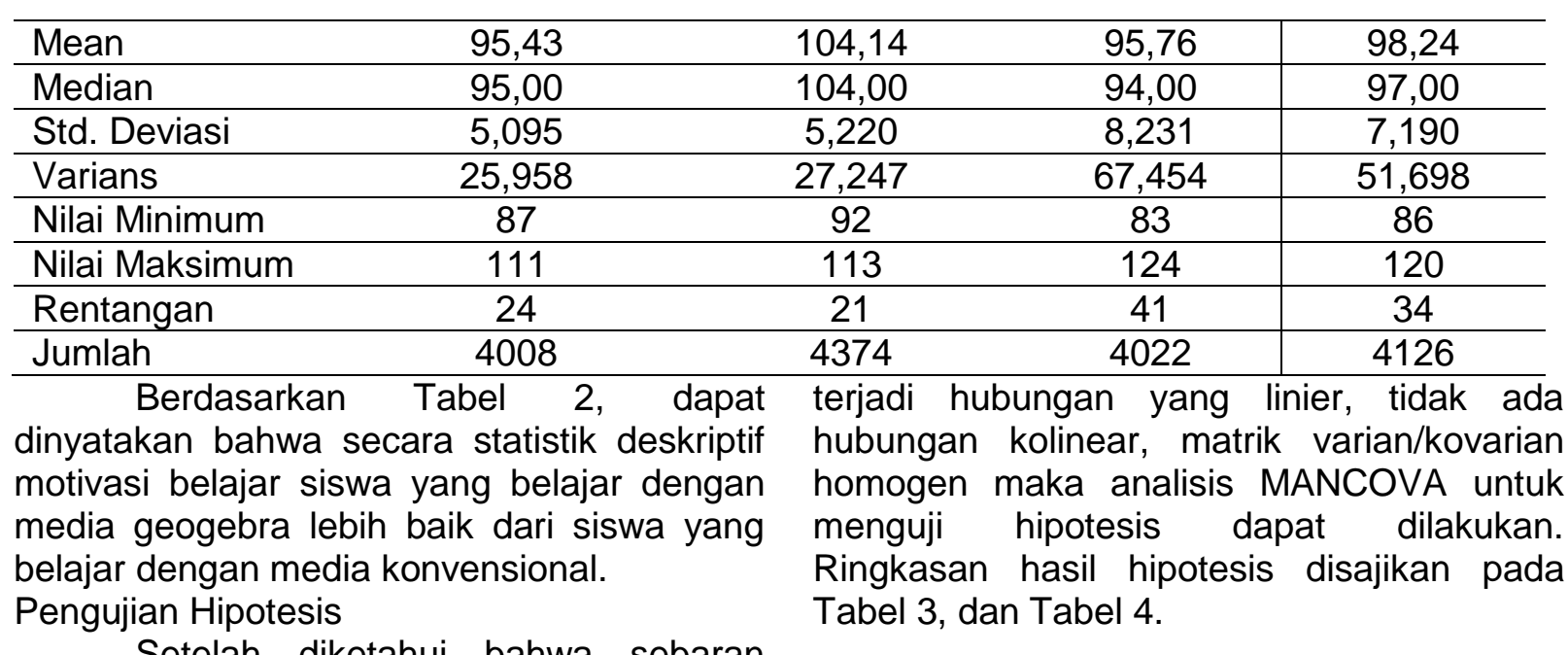

Setelah diketahui bahwa sebaran

data normal dan varians homogen, tidak

Tabel 3 Ringkasan Hasil Uji Mancova

\begin{tabular}{|llccccc}
\hline \multirow{4}{*}{ Effect } & & \multicolumn{5}{c}{ Hypothesis } \\
\hline Intercept & & Value & F & df & Error df & Sig. \\
& Pillai's Trace & 0,198 & $9,747^{\mathrm{a}}$ & 2,000 & 79,000 & 0,000 \\
& Wilks' Lambda & 0,802 & $9,747^{\mathrm{a}}$ & 2,000 & 79,000 & 0,000 \\
& Hotelling's Trace & 0,247 & $9,747^{\mathrm{a}}$ & 2,000 & 79,000 & 0,000 \\
& Roy's Largest Root & 0,247 & $9,747^{\mathrm{a}}$ & 2,000 & 79,000 & 0,000 \\
\hline PREMOTIVASI & Pillai's Trace & 0,625 & $65,707^{\mathrm{a}}$ & 2,000 & 79,000 & 0,000 \\
& Wilks' Lambda & 0,375 & $65,707^{\mathrm{a}}$ & 2,000 & 79,000 & 0,000 \\
& Hotelling's Trace & 1,663 & $65,707^{\mathrm{a}}$ & 2,000 & 79,000 & 0,000 \\
& Roy's Largest Root & 1,663 & $65,707^{\mathrm{a}}$ & 2.000 & 79,000 & 0,000 \\
\hline PREKREATIFITAS & Pillai's Trace & 0,727 & $105,038^{\mathrm{a}}$ & 2,000 & 79,000 & 0,000 \\
& Wilks' Lambda & 0,273 & $105,038^{\mathrm{a}}$ & 2,000 & 79,000 & 0,000 \\
& Hotelling's Trace & 2,659 & $105,038^{\mathrm{a}}$ & 2,000 & 79,000 & 0,000 \\
& Roy's Largest Root & 2,659 & $105,038^{\mathrm{a}}$ & 2,000 & 79,000 & 0,000 \\
\hline MP & Pillai's Trace & 0,782 & $141,405^{\mathrm{a}}$ & 2,000 & 79,000 & 0,000 \\
& Wilks' Lambda & 0,218 & $141,405^{\mathrm{a}}$ & 2,000 & 79,000 & 0,000 \\
& Hotelling's Trace & 3,580 & $141,405^{\mathrm{a}}$ & 2,000 & 79,000 & 0,000 \\
& Roy's Largest Root & 3,580 & $141,405^{\mathrm{a}}$ & 2,000 & 79,000 & 0,000 \\
\hline
\end{tabular}

Tabel 4 Ringkasan Hasil Uji Pengaruh Antar Subyek 


\begin{tabular}{|c|c|c|c|c|c|c|}
\hline Source & Dependent Variable & $\begin{array}{l}\text { Type III } \\
\text { Sum of } \\
\text { Squares }\end{array}$ & $\mathrm{df}$ & $\begin{array}{c}\text { Mean } \\
\text { Square }\end{array}$ & $\mathrm{F}$ & Sig. \\
\hline \multirow[t]{2}{*}{ Corrected Model } & POSMOTIVASI & $2737,012^{a}$ & 3 & 912,337 & 59,246 & 0,000 \\
\hline & POSKREATIFITAS & $9058,190^{\mathrm{b}}$ & 3 & 3019,397 & 127,079 & 0,000 \\
\hline \multirow[t]{2}{*}{ Intercept } & POSMOTIVASI & 216,001 & 1 & 216,001 & 14,027 & 0,000 \\
\hline & POSKREATIFITAS & 57,557 & 1 & 57,557 & 2,422 & 0,124 \\
\hline \multirow[t]{2}{*}{ PREMOTIVASI } & POSMOTIVASI & 1999,213 & 1 & 1999,213 & 129,825 & 0,000 \\
\hline & POSKREATIFITAS & 8,955 & 1 & 8,955 & 0,377 & 0,541 \\
\hline \multirow[t]{2}{*}{ PREKREATIFITAS } & POSMOTIVASI & 0,232 & 1 & 0,232 & 0,015 & 0,903 \\
\hline & POSKREATIFITAS & 4816,780 & 1 & 4816,780 & 202,727 & 0,000 \\
\hline \multirow[t]{2}{*}{ MP } & POSMOTIVASI & 792,966 & 1 & 792,966 & 51,494 & 0,000 \\
\hline & POSKREATIFITAS & 4324,745 & 1 & 4324,745 & 182,018 & 0,000 \\
\hline \multirow[t]{2}{*}{ Error } & POSMOTIVASI & 1231,941 & 80 & 15,399 & & \\
\hline & POSKREATIFITAS & 1900,798 & 80 & 23,760 & & \\
\hline \multirow[t]{2}{*}{ Total } & POSMOTIVASI & 864088,000 & 84 & & & \\
\hline & POSKREATIFITAS & 960941,000 & 84 & & & \\
\hline \multirow[t]{2}{*}{ Corrected Total } & POSMOTIVASI & 3968,952 & 83 & & & \\
\hline & POSKREATIFITAS & 10958,988 & 83 & & & \\
\hline
\end{tabular}

Berdasarkan hasil analisis data penelitian, ditemukan bahwa: (1) setelah perlakuan dikontrol dengan kovariabel pramotivasi dan prakreativitas terdapat perbedaan yang signifikan motivasi belajar dan kreativitas antara siswa yang mengikuti pembelajaran dengan menggunakan media berbasiskan geogebra dibandingkan dengan siswa yang mengikuti pembelajaran dengan media konvensional $(F=141,405 ; p<0,05)$. (2) setelah perlakuan dikontrol dengan kovariabel pramotivasi dan prakreativitas terdapat perbedaan signifikan variabel motivasi belajar antara siswa yang mengikuti pembelajaran dengan media berbasiskan geogebra dibandingkan dengan siswa yang mengikuti pembelajaran dengan media konvensional $(F=51,494 ; p<0,05)$. (3) setelah perlakuan dikontrol dengan kovariabel pramotivasi dan prakreativitas terdapat perbedaan signifikan variabel kreativitas antara siswa yang mengikuti pembelajaran dengan media berbasiskan geogebra dibandingkan dengan siswa yang mengikuti pembelajaran dengan media konvensional( $F=182,018 ; p<0,05)$.

Hasil yang diperoleh dalam penelitian ini sesuai dengan pendapat Clements (dalam Dewi Padmo, 2004) yang menyatakan bahwa pembelajaran geometri dengan komputer perlu dilakukan karena disamping siswa termotivasi untuk menyelesaikan masalahmasalah geometri, komputer juga dapat membuat konsep-konsep yang abstrak dalam geometri menjadi konkret dan jelas. Selain itu, pembelajaran media GeoGebra mengakibatkan siswa termotivasi untuk belajar. Hal ini sejalan dengan pendapatnya Bruner (Sardiman 2004: 46) yang mengemukakan bahwa jika dalam belajar siswa dapat diberi pengalaman langsung (melalui media, demonstrasi, fieldtrip, dramatisasi), maka situasi pengajarannya akan meningkatkan kegairahan dan minat siswa tersebut dalam belajar.

Di lain pihak, pembelajaran dengan 
media konvensional mengarahkan pada aktivitas meniru atau mengkopi, di mana proses pembelajarannya menyebabkan siswa melakukan pengulangan dan informasi baru disajikan dalam bentuk laporan, kuis, atau tes (Jackson dalam Suastra, 2009). Pembelajaran dengan media konvensional jarang melibatkan pengaktifan pengetahuan awal dan jarang memotivasi siswa untuk memproses pengetahuannya sehingga akan berdampak rendahnya kreatifitas siswa dalam pembelajaran. Peran guru dalam pembelajaran dengan media konvensional adalah sebagai sumber pengetahuan dan siswa adalah orang yang diberi pengetahuan tersebut. Berdasarkan asumsi tersebut, pembelajaran dengan media konvensional diawali dengan penyajian materi pelajaran yang terkait oleh guru kepada siswa. Teori, konsep, ataupun prinsip-prinsip dari materi pembelajaran diharapkan dapat dikuasai oleh siswa dipaparkan terlebih dahulu di depan kelas oleh guru. Setelah itu, barulah siswa diwajibkan untuk bekerja dalam kelompok kecil dalam melakukan percobaan dan menyelesaikan soal-soal dalam LKS yang disediakan oleh guru sehingga tanggung jawab siswa terhadap pembelajaran dirinya sendiri menjadi kecil, sebab siswa belajar hanya semata-mata karena guru memberikan tugas kepada siswa untuk mempelajari materi ajar tersebut. Hal ini akan mengurangi kemandirian siswa dalam belajar untuk membentuk pengetahuannya sendiri sehingga berdampak pada kemampuan berpikir siswa yang menyebabkan kreatifitas dan motivasi belajar siswa menjadi lebih rendah.

Temuan dalam penelitian ini memberikan petunjuk bahwa pembelajaran dengan media geogebra memiliki keunggulan komparatif dibandingkan dengan media konvensional dalam hal meningkatkan kreatifitas dan motivasi belajar siswa. Berdasarkan hal tersebut maka implikasi yang dapat diberikan adalah kreatifitas belajar dan motivasi belajar siswa dapat ditingkatkan dengan menerapkan pembelajaran menggunakan media geogebra. Pada pembelajaran yang menggunakan media geogebra, siswa aktif terlibat dalam kegiatan pembelajaran. Hal ini dapat menimbulkan motivasi intrinsik siswa untuk lebih bertanggung jawab dalam kegiatan pembelajaran. Pada pembelajaran yang menggunakan media geogebra, guru berperan sebagai fasilitator dan mediator. Hal ini memberikan implikasi bahwa guru hendaknya memiliki kemampuan yang baik dalam mengoperasikan komputer terutama dalam penggunaan media yang berbasiskan geogebra.

\section{PENUTUP}

Berdasarkan uraian di atas, simpulan penelitian ini adalah sebagai berikut. Pertama, setelah perlakuan dikontrol dengan kovariabel pramotivasi dan prakreativitas terdapat perbedaan yang signifikan motivasi belajar dan kreativitas antara siswa yang mengikuti pembelajaran dengan menggunakan media berbasiskan geogebra dibandingkan dengan siswa yang mengikuti pembelajaran dengan media konvensional dengan. Kedua, setelah perlakuan dikontrol dengan kovariabel pramotivasi dan prakreativitas terdapat perbedaan signifikan variabel motivasi belajar antara siswa yang mengikuti pembelajaran dengan media berbasiskan geogebra dibandingkan dengan siswa yang mengikuti pembelajaran dengan media konvensional. Ketiga, setelah perlakuan dikontrol dengan kovariabel pramotivasi dan prakreativitas terdapat perbedaan signifikan variabel kreativitas antara siswa yang mengikuti pembelajaran dengan media berbasiskan geogebra dibandingkan dengan siswa yang mengikuti pembelajaran dengan media konvensional. Media geogebra lebih unggul dibandingkan media konvensional dalam pencapaian motivasi belajar dan kreativitas siswa.

\section{UCAPAN TERIMA KASIH}

Ucapan terima kasih saya sampaikan kepada Prof. Dr. I Wayan Santyasa, M.Si, sebagai pembimbing I dan Dr. Ketut Agustini, S.Si.,M.Si sebagai pembimbing II yang telah dengan sabar membimbing, mengarahkan dan memberikan motivasi sehingga penulis mampu melewati berbagai halangan dan tantangan dalam studi dan penyelesaian tesis ini, beserta semua pihak yang telah membantu penulis selama menempuh pendidikan. 


\section{DAFTAR PUSTAKA}

Dewi Padmo. 2004. Teknologi Pembelajaran: Peningkatan Kualitas Belajar Melalui Teknologi Pembelajaran. Jakarta: Pustekom.

Hamalik, O. 2001. Proses Belajar Mengajar. Jakarta: Bumi Aksara.

Hawadi, R. A, Darmo Wiharjo, R. \& Wiyono, M. 2001. Kreativitas. Jakarta: PT Gramedia Widiasarana Indonesia.

Kunandar. 2007. Guru profesional. Jakarta: PT RajaGrafindo Persada.

Sardiman. 2006. Interaksi dan Motivasi Belajar Mengajar. Jakarta: PT Raja Grafindo Persada.

Suastra, I W. 2009. Pembelajaran sains terkini. Singaraja: Undiksha.

Munandar, S. C. 1992. Mengembangkan bakat dan kreativitas anak sekolah.Jakarta:GramediaWidiasarana

Saroso, S. 2008. Upaya pengembangan pendidikan melalui pembelajaran berbasis multimedia.Tersedia pada http://media.diknas.go.id/media/ document/5650.pdf.

Shadaan, P \& Kwan Eu, L. 2014. Effectiveness of using geogebra on students' understanding learning circles - The Malaysian Online Jurnal of Education Technology. 1(4). 1-11. Tersedia pada : http.//www.mojet.net . ( Diakses 5 Agustus 2015 )

Nopiyanti. N. L. P.A. 2014. Pengembangan perangkat pembelajaran geometri berbantuan geogebra dalam upaya meningkatkan keterlibatan dan prestasi belajar matematika siswa kelas VII.EJournal Program Pascasarjana Undiksha (3).Tersedia pada :http://pasca.undiksha.ac.id/e-journal. (Diakses 5 Agustus 2015) 
Jurnal Teknologi Pembelajaran Indonesia

ISSN: 2615-2797(Print) | ISSN: 2614-2015 (Online) Volume 8 Nomor 3 Tahun 2018 